\title{
CORPORATE SOCIAL RESPONSIBILITY AS A WAY TO SUSTAINABLE EMPLOYMENT
}

\section{Karolina Muszyńska}

Wroclaw University of Economics and Business, Wrocław, Poland

e-mail: karolina.muszynska@ue.wroc.pl

ORCID: 0000-0001-5951-5867

\section{(C) 2020 Karolina Muszyńska}

This work is licensed under the Creative Commons Attribution-ShareAlike 4.0 International License. To view a copy of this license, visit http://creativecommons.org/licenses/by-sa/4.0/

Quote as: Muszyńska, K. (2020). Corporate social responsibility as a way to sustainable employment. Econometrics. Ekonometria. Advances in Applied Data Analysis, 24(3).

DOI: 10.15611/eada.2020.3.05

JEL Classification: O15, J7, M5

\begin{abstract}
The purpose of this article is to identify the relationship between the declared activities in line with corporate social responsibility and the implementation of diversity management concepts. The paper presents the essence of corporate social responsibility as an element of company strategy, and the importance of the concept of managing diversity of employees in building an organizational culture based on mutual respect and a sense of security of employees, and thus increasing the efficiency and innovation of the company, by recognizing the individual characteristics of the people employed. An in-depth interview method was used, conducted on the basis of a non-standardized interview questionnaire with HR directors of domestic companies. The obtained empirical material was presented as a case study.
\end{abstract}

Keywords: corporate social responsibility, diversity, business strategy, sustainable development.

\section{Introduction}

The concept of corporate social responsibility fits directly into the implementation of sustainable development objectives, which was initially interpreted primarily in terms of eco-development. Gradually, as awareness of the importance of achieving the objectives contained in the sustainable development agenda for the quality of life grew, there was also a growing interest in expanding the voluntary activities of enterprises, and the CSR concept took a key place in the strategy of many enterprises.

The motives for addressing the topic of the article were the numerous challenges faced by organizations resulting from the demographic processes, globalization and the development of technology, which are significantly affecting the structure of labour markets. 
A reconstruction of human resources management is underway, aiming at recognizing diversity as a new paradigm (Pocztowski, 2018, p.146; Urbaniak, 2014, p. 63) and the capital-wise approach to employees who, having their own capital and caring for its development, enter into a relation with the employer, offering their commitment in return for individual adaptation and investment in their development (Borkowska, 2010, p. 16 etc.; Strużyna, 2010, p. 20 etc.). Employee-organization relations are changing as an employee's emotional relationship with the company is being replaced by a rational commitment based on comparing the value of an individual's contribution to the value of the benefits obtained in return (Mendryk, 2019 , p. 8). Looking at this process from a global perspective, it can be seen that three groups of employees occupy a special place in the recruitment strategies of companies that focus on diversity: women, employees over 50, and people with disabilities. The idea behind the implementation of diversity management is the concept of corporate social responsibility (CSR).

\section{The impact of CSR on the integration of diversity management into an enterprise strategy}

With the implementation of social systems in organizations, it is becoming increasingly important to create an appropriate work environment for internal stakeholders which will enable the selection of employees from the full pool of talent available on the labour market. Therefore, today's organizations are increasingly aware of the challenges they face when it comes to addressing employee diversity.

In order to compete, companies are focused on creating work systems based on high efficiency, which also requires greater innovation, and on building employee commitment, increasing the use of their knowledge, skills and experience stemming from diversity.

\subsection{Corporate social responsibility as part of a company strategy}

In Poland, CSR was initiated by the establishment of the Responsible Business Forum in 2000, a non-governmental organization promoting the comprehensive implementation of this idea. One of the first promoted definitions states that corporate responsibility is such a "management strategy which, by engaging in social dialogue at local level, contributes to the growth of competitiveness of a given enterprise at global level and at the same time creates favourable conditions for economic, social and environmental development" (Forum Odpowiedzialnego Biznesu, 2020). CSR was identified with sustainable development and emphasis was placed on dialogue with stakeholders. Another definition was nearly identical with the EU version contained in the "CSR Green Paper" of 2001 (Green Paper, 2001), "responsible business is a voluntary strategy that takes into account social, ethical and environmental aspects in business activities and in contacts with stakeholders". Three 
key issues were highlighted there - firstly, the ethical dimension of responsibility, i.e. acting in accordance with socially accepted ethical standards, which translated into the popularity of strategic philanthropy and ethical programmes in enterprises. Secondly, the definition emphasized the fact that Corporate Social Responsibility was voluntary, which gave rise to controversy inasmuch as this type of activity should only be voluntary, and how much legal regulation is required to force companies to take into account various social and environmental aspects. As a consequence, for a long time the CSR concept was treated marginally as an additional element, not a wholesome component of the strategy (Rok, 2007). Thirdly, the concept of a stakeholder was introduced, i.e. "any identifiable group or entity (institution, including the natural environment) that can exert influence, or is influenced by the enterprise (organisation) through its strategies, products and manufacturing processes, management systems and procedures" (Rok, 2001). The theory of stakeholders, along with the development of CSR, has become the essence of this concept, therefore another, improved definition of Corporate Social Responsibility appeared: "CSR is the process of getting to know and incorporating the changing expectations of stakeholders in the management strategy, as well as monitoring the impact of such a strategy on the competitiveness and value of the company on the market" (Rok, 2008). In 2010, in order to create an international definition of CSR, the ISO 26000 standard was published, stating that "the responsibility of an organization for the impact of its decisions and activities on society and the environment, resulting in ethical behaviour and transparency which contributes to sustainable development, including the health and well-being of society; takes into account the expectations of stakeholders (persons or groups who are interested in the decisions or actions of the organization); complies with current laws and is consistent with international standards of behaviour, and is integrated throughout the organization and implemented in its relations" (PN-ISO 26000, 2012). This takes into account all issues relevant to the idea of social responsibility (of business) mentioned in the previous definitions, i.e. transparency, ethics, compliance with the law, implementation of sustainable development, meeting the expectations of stakeholders, reference to the entire organization and its supply chain.

The concept of corporate social responsibility fits directly into the implementation of sustainable development objectives, which was initially interpreted primarily in terms of eco-development. Gradually, as awareness of the importance of achieving the objectives contained in the sustainable development agenda for the quality of life grew, there was also a growing interest in expanding the voluntary activities of enterprises, and the CSR concept took a key place in the strategy of many enterprises.

Many initiatives are being launched in pursuit of the sustainable development objectives of Agenda 2030. In addition, numerous legal regulations and conventions on diversity management principles are being developed. We have seen a significant increase in the awareness of enterprises of the need to implement the CSR concept in a permanent strategy in order to increase innovation, achieve better risk management, 
more effective motivation of employees, and economic growth. More and more companies are recognising the benefits of diversity management.

\subsection{Diversity management as a new paradigm for using human capital}

The concept of diversity management emerged in Europe in the late 1980s as a response to the dynamic demographic changes, such as: an ageing population and increased migration, increased professional aspirations of women, and changes in family roles, as well as increasing globalisation (Jędrych and Berniak-Woźny, 2017). The concept of diversity can be interpreted in many ways depending on the focus of researchers. With regard to employees, it is assumed that the source of diversity are all aspects in which people differ. They can be visible, e.g. age, gender, race, fitness, and invisible, e.g. education, knowledge, experiences, skills, personality, and value system. Sweeney and McFarlin defined diversity management as an approach to managing people in an organization that aims to build and sustain a supportive work environment for employees by recognizing their individuality and diversity due to characteristics such as gender, age, race, ethnicity, disability and others, whether social or demographic (Sweeney and McFarlin, 1992). The concept has gradually evolved and gained new elements. Thomas defined diversity management as the aggregated effect of human resource management aimed at achieving competitive advantage through leadership and teamwork (Thomas, 2004). This allows for the effective use of the pool of talent available on the labour market, as it assumes the creation of such institutional conditions in the organisation in which every employee has a chance to develop (Billing and Sundin, 2006). The aim of the concept is to provide equal opportunities in the workplace and to make full use of employees' potential by recognising the differences between people within and outside the organisation and consciously developing strategies, policies and programmes that create a climate for respecting and exploiting these differences for the benefit of the organisation (Anand and Winters, 2008). The skilful management of diversity in the workplace can often provide tangible benefits to companies (Kirton and Greene, 2010). The main goal of diversity management is to create a work environment where every employee feels respected and valued, so that they can fully exploit their intellectual potential, which contributes to the success of the organisation (Kaczmarek, Krajnik, Morawska-Witkowska, Roch Remisko, and Wolsa, 2009). The implementation of a diversity strategy can also be an important aspect of building a positive image of the organisation, creating its brand as an employer of choice, and is part of the corporate social responsibility trend (Lipka, 2000). The systemic approach to diversity management proposes to analyze it in the context of five components (Rakowska and Cichorzewska, 2016):

- diversity paradigms (a collection of views of management views, their values, and beliefs related to diversity management);

- policies (an organization's objectives in managing the diversity of resources); 
- programmes (a set of formalised activities related to diversity management in an organisation);

- practices (implementation of programs in the organization, experience with the implementation of diversity management programs by lower level managers and employees);

- climate (employees' perceptions and interpretations of diversity management and practices and programmes).

Diversity management can also be considered at three levels of identity: primary, secondary and organisational (Billing and Sundin, 2006). The primary identity includes features such as gender, age, physical fitness, sexual orientation, personality, race, origin, nationality and language. Therefore these are, in a way, elements inherent in every human being. Managing diversity in the context of the secondary identity is characterized by place of residence, material status, income, education, family situation, religion, appearance, interests, culture, lifestyle, values, attitudes, marital status, fertility and religion. These are the elements on which a person has influence, and can create them. The level of organizational identity includes: the position held, the nature of work performed, membership in the organization, place in the organizational structure, professional licences held, rules of remuneration, scope of professional duties and seniority. These are features independent of a human being, requiring adaptation to the environment. The secondary and the organisational identities are linked with the place that a person occupies in society - they refer to the roles and functions he or she performs in his or her private and professional life (Kwiatek, 2014).

\section{Research methodology}

The aim of the article is to identify the relationship between the declared activities consistent with the social responsibility of business and the implementation of the concept of diversity management. The implementation of the set goal was possible through the application of the research method of in-depth interview conducted on the basis of a non-standardized interview questionnaire with HR managers of domestic companies. The research was carried out in three service and production companies in debt collection, pharmaceutical and medical sectors, and manufacturing industry, with prior verification that the companies declare their commitment to corporate social responsibility.

Empirical research was conducted in order to find answers to the research questions raised:

1. Is there a link between the measures taken to promote corporate social responsibility and diversity management?

2. What are the socially responsible actions taken by companies in the field of diversity management with regard to the different characteristics of their employees? 
The article presents the specific features of three companies for which the differences and similarities between the incorporation of the CSR concept into the company strategy and diversity management of employees are characterized. To assess the attitude of management to the reconstruction of the existing employment structure, it is recommended to conduct further research among enterprises operating in the indicated industries.

\subsection{The debt collection industry}

The debt collection company, which includes a number of companies with international reach, employs 1,600 people in Poland. The company offers a wide range of services in the field of debt management. The concept of corporate social responsibility is a central point of the company's PR activities, whose principles are inscribed in the company's mission. Moreover, the company has subscribed to the Good Practices Principles developed by the Association of Financial Enterprises in Poland. These are 16 general and universal principles, which are an expression of the basic values and ethical ideals guiding financial enterprises. Due to the industry the company operates in, it is considered an important element of society. It conducts its activities with the overriding aim to bring about settlement for the benefit of both parties, treating the stakeholders as clients and not debtors. It undertakes numerous educational initiatives to advance society's awareness about good practices in preventing debt, and treats the process of implementing the concept of corporate social responsibility into the company's strategy in a natural way, without barriers. The company considers it important to improve the image of the entire debt collection industry in the eyes of the clients and the proportion of people who have not fallen into debt thanks to their educational programmes.

The company has also signed the Diversity Charter, an international initiative under the patronage of the European Commission. The Charter aims to promote equality and diversity management in the workplace.

The Diversity Management concept is based on a consolidation model that uses diversity in all areas of the organisation. Diversity is part of the organisational culture of a female-type company and is presented in the form of implementation materials. The incentive for the implementation of the concept of diversity management was the internal need of the Management Board to create an organization based on mutual respect among employees, good relations, care for their job security and concern for quality of life. The main areas of diversity on which the enterprise focuses are gender equality and disability. In order to ensure equality between women and men, the company has implemented a pay management policy. An important barrier in the fight against gender-based pay is the fact that women often request lower wages than men during their job interviews and, during their 10-year career path, women take a maternity break, which delays their promotion. Measures to combat inequalities include narrowing the wage range for a given position, which will allow for the equalisation of wages and programmes to facilitate return to work after parental leave. 
The aspect of disability among employees has been taken care of from the very beginning of the company's operation through the selection of an appropriate building for headquarters with the necessary facilities for the disabled. No barriers were detected in this area. The HR team is expected to consider the CVs of all the candidates in terms of their skills and experience, without discriminating against anyone due to their different characteristics.

\subsection{Pharmaceutical and medical industry}

The Group in question consists of companies operating in various branches of the pharmaceutical industry and medical services. It employs over 1500 people and has a dedicated CSR department which implements the objectives and tasks written down in the form of the statute of the Foundation established in 2006 for disabled athletes. In addition, the company provides financial support for orphanages, organizes employee volunteering and cyclical events to create a bond between the employees with the local community. Socially responsible practices addressed to the most needy and, at the same time an often overlooked niche from the very beginning of the Group's existence have been part of company strategy. The comprehensive care of the health of employees and their families is of crucial importance for the company. To this end, it supports, among others, a children's hospital. No barriers have been encountered in the implementation of the CSR concept in the company strategy, which may be due to the fact that the actions taken have from the beginning been an integral part of the Group's mission.

The concept of diversity management is based on a consolidation model that takes advantage of diversity in all areas of the organisation. It approaches human capital as a pool of talent available on the labour market which should be used effectively by creating such institutional conditions in the organisation in which every employee has the chance to develop. Managing employee diversity is the domain of the HR Department, which approaches each candidate individually, paying attention to his or her competences and potential contribution to the position, rather than the specific characteristics he or she represents. The rules of conduct are set out in the form of internal procedures. The areas of focus are generational management and gender equality.

The company has a well-developed mentoring programme, where older employees share their knowledge and experience with young people at the beginning of their career. This allows for the creation of a transparent organisational structure and for filling the generational gap between generations $\mathrm{X}$ and $\mathrm{Y}$, which was initially a barrier. Junior employees representing different attitudes than their seniors often prefer to implement innovative actions rather than to base their actions on developed paths. Knowledge transfer allows for mutual exchange of opinions and ideas, which leads to more effective results. The second aspect of diversity management is equal opportunities for women and men on the labour market. More than $70 \%$ of 
women are employed in the entire company, including those in managerial positions. The phenomenon of the glass ceiling, which does not allow women to climb up the career ladder, is being eliminated. The barriers encountered in this respect are the attitude of managers, who were afraid of losing a valuable employee at a crucial moment due to, e.g. maternity leave. Changes had to be introduced at the core, i.e. in the mentality of employees, by creating an organisational culture based on mutual respect and trust.

The benefits resulting from the introduction of the CSR and HR policies consist in the creation of a sense of influence on the company's operations among both upper and lower-level employees, a feeling of security and mutual respect, as well as an individual approach to everyone and care for their personal development. The above mentioned activities enhance the loyalty of employees who willingly pursue their whole career path in one company.

\subsection{Manufacturing industry}

This subsidiary of an international manufacturing company has been operating on the Polish market for 25 years and employs a total of over five thousand people. Work on key concepts for the company's strategy, such as CSR and diversity management, is carried out at the head office, then cascaded to subsidiaries in specific countries. Depending on the business profile, initiatives for corporate social responsibility are undertaken primarily in environmental areas such as the reduction of $\mathrm{CO}_{2}$ emissions, reduction of energy and water consumption and waste segregation, and the promotion of employee health and safety. Moreover, the company supports employee volunteering through cooperation with local communities, e.g.by providing aid to orphanages.

The perceived benefits resulting from the implementation of the CSR concept in the company's strategy include a positive impact on the user of the company's products. Issues such as the environment, climate, compliance with the law, and ethical conduct become more and more important for internal and external interests.

The concept of diversity management has been implemented in the company together with socially responsible activities. It is now based on a business model in which diversity is an important element in building competitive advantage. The concept is an integral part of the business strategy by recognising the individualism of diversity and thus using diverse experiences, knowledge, skills, aptitudes and sensibilities to the benefit of the organisation and its employees. The areas of focus are age and multicultural management, gender equality and the resulting acceptance of different plans for life, career, professional and private goals. The aim of the organisation is to create a corporate culture in which every employee has the opportunity to fully exploit his or her potential.

The company implements numerous mentoring and development programmes allowing for the transfer of knowledge and experience between different generations 
and genders. Internal recruitment is supported, thanks to which lower-level employees have the possibility of promotion. When selecting the right candidate, only his/ her competences and potential matter, and no profiling of any other characteristics is carried out. Barriers noted during the implementation of the above mentioned programmes are mainly due to stereotypes and the self-perception of employees who see themselves as not good enough for a given position or salary. In addition, there was noted a growing distance between employees, which may result from fear of diversity. In order to combat discriminatory behaviour, measures are being taken to integrate workers, such as family picnics, employee volunteering, etc. The company does not have a uniform, formally written code of conduct. Initiatives are treated as a series of 'procedures' or practices for equal aspects of diversity management.

\section{Conclusion}

This research made it possible to check the link between the declared activities consistent with the corporate social responsibility, and the implementation of the concept of diversity management. The decision to implement the CSR and diversity management concepts into the strategy is made at the same time by the Board of Management. There is a high degree of consistency between the activities for the benefit of external and internal stakeholders, e.g. through the organisation of employee volunteering, which allows employees to get involved in such activities and have an impact on the local community.

The strongest link between the actions taken for the social responsibility of business and diversity management is declared by the pharmaceutical company, for which it is crucial to take comprehensive care of the health of employees and their families, and therefore it actively supports a children's hospital. The manufacturing company pays special attention to issues related to the environment, climate, legal compliance and ethical conduct, which are often an important factor in making choice for both buyers and potential employees who, in the era of intense competition, choose companies that act according to their values. The debt-collection company, whose organizational culture is based on mutual respect and tolerance, treats all stakeholders equally and combats discrimination.

The differences in the process of the implementation of the discussed concepts of corporate social responsibility and diversity management into the strategy of an enterprise result from the specific nature of the industry in which such a company operates, and which makes it focus on different issues. For the financial sector it is important to educate the stakeholders how to manage their funds rationally, while the pharmaceutical sector focuses on health aspects. However, there is a similarity in the implementation of the two concepts. Companies make efforts to ensure that the image created in the eyes of consumers is consistent with the opinion of the employees about their employer. 
The turbulent market environment and demographic, social and technological changes as well as the expectations of the external environment require companies to be flexible and adapt to the prevailing conditions. Therefore, it is necessary to continue activities aimed at the elimination of prejudices and stereotypes in the organisation, elimination of inequalities, promotion of the valid legal regulations, organisation of training programmes raising the awareness of management, and creation of tools enabling reliable and objective assessment of the organisation from the point of view of diversity management.

The paper presents three case studies made with material obtained based on in-depth interviews conducted using a non-standardized interview questionnaire with HR directors of business enterprises operating in the debt collection, pharmaceutical and industrial sectors. The answer was given in relation to the fragmentary presentation of the job search situation. It is recommended to search for companies operating in the indicated industries. This will allow for supervising over the inspection of management staff to reconstruct the existing employment structure and identifying what advantages and disadvantages they see in taking such actions.

\section{References}

Anand, R., and Winters, M. F. (2008). A retrospective view of corporate diversity training from 1964 to the present. Academy of Management Learning \& Education, 7(3), 356-372.

Billing, Y. D., and Sundin, E. (2006). From managing equality to managing diversity: A critical Scandinavian perspective on gender and workplace diversity. In A. M. Konrad, P. Prasad, and J. K. Pringle (Eds.), Handbook of workplace diversity. London: SAGE Publications.

Borkowska, S. (2010). Równowaga między pracą a życiem pozazawodowym. Acta Universitatis Lodziensis. Folia Oeconomica, (240), 5-44.

Forum Odpowiedzialnego Biznesu. (2020). Jakie korzyści niesie równość na rynku pracy? Trwa kampania informacyjna z okazji 8. Targów CSR. Retrieved from http://odpowiedzialnybiznes.pl/aktualno\%C5\%9Bci/jakie-korzysci-niesie-rownosc-na-rynku-pracy-trwa-kampania-informacyjnaz-okazji-8-targow-csr/

Green Paper. (2001). Promoting a European framework for Corporate Social Responsibility. Commission of the European Communities. Brussels, COM(2001) 366 final.

Jędrych, E., and Berniak-Woźny, J. (2017). Kształtowanie kapitału społecznego organizacji. Warszawa: Wydawnictwo Naukowe PWN.

Kaczmarek, P., Krajnik, A., Morawska-Witkowska, A., Roch Remisko, B., and Wolsa, M. (2009). Fir$m a=$ różnorodność. Zrozumienie, poszanowanie, zarządzanie. Warszawa: Forum Odpowiedzialnego Biznesu.

Karta Różnorodności. (2016). Retrieved from http://odpowiedzialnybiznes.pl/karta-roznorodnosci/dokument/

Kirton, G., and Greene, A. M. (2010). The dynamics of managing diversity. A critical approach. Oxford: Elsevier, Butterworth-Heinemann.

Kwiatek, A. (2014). Społeczna odpowiedzialność a różnorodność w organizacji. Retrieved from http:// www.ue.katowice.pl

Lipka, A. (2000). Strategie personalne firmy. Kraków: Wydawnictwo Profesjonalnej Szkoły Biznesu. 
Mendryk, I. (2019). Uczestnictwo w organizacji w perspektywie różnorodności wiekowej. Warszawa: Wydawnictwo C.H. Beck.

PN-ISO 26000. (2012). Wytyczne dotyczące społecznej odpowiedzialności. Warszawa: PKN.

Pocztowski, A. (2018). Zarzadzanie zasobami ludzkimi. Warszawa: PWE.

Rakowska, A., and Cichorzewska, M. (2016). Zarządzanie różnorodnością zasobów ludzkich w innowacyjnych przedsiębiorstwach - wyniki badań. Przedsiębiorczość i Zarządzanie, 17(2), III.

Rok, B., (2001). Nasz kapitał. Biuletyn Forum Odpowiedzialnego Biznesu, (1).

Rok, B. (2007). Etyczność, ekonomiczność i efektywność koncepcji społecznej odpowiedzialności biznesu. In A. Lewicka-Strzałecka (Ed.), Wspótczesne wyzwania nauk praktycznych. Warszawa: Wydawnictwo Wyższej Szkoły Przedsiębiorczości i Zarządzania im. Leona Koźmińskiego.

Rok, B., (2008). Biznes społecznie odpowiedzialny - teoria i praktyka. In J. Hausner (Ed.), Ekonomia społeczna a rozwój. Kraków: MSAP.

Strużyna, J., (2010). Ewolucja strategicznego zarządzania zasobami ludzkimi. Zarzadzanie Zasobami Ludzkimi, (3-4), 11-28.

Sweeney, P. D., and McFarlin, D. B. (1992). Workers` evaluations of the "ends" and the "means": An examination of four models of distributive and procedural justice. Organization Behavior and Human Decision Processes, (55).

Thomas, D. A. (2004). Diversity as strategy. Harvard Business Review, 82(9).

Urbaniak, B. (2014). Zarządzanie różnorodnością zasobów ludzkich w organizacji. Zarządzanie Zasobami Ludzkimi, (3/4).

\section{SPOLECZNA ODPOWIEDZIALNOŚĆ BIZNESU JAKO DROGA DO ZRÓWNOWAŻONEGO ZATRUDNIENIA}

Streszczenie: Celem niniejszego artykułu jest identyfikacja związku między deklarowanymi działaniami zgodnymi ze społeczną odpowiedzialnością biznesu a wdrażaniem koncepcji zarządzania różnorodnością. W opracowaniu przedstawiono istotę społecznej odpowiedzialności jako elementu strategii przedsiębiorstwa oraz znaczenie koncepcji zarządzania różnorodnością pracowników w budowaniu kultury organizacyjnej opartej na wzajemnym szacunku i poczuciu bezpieczeństwa pracowników, a tym samym zwiększaniu efektywności i innowacyjności przedsiębiorstwa poprzez dostrzeganie indywidualnych cech zatrudnionych osób. Wykorzystana została metoda badawcza wywiadu pogłębionego przeprowadzonego na podstawie niestandaryzowanego kwestionariusza wywiadu wśród dyrektorów personalnych krajowych przedsiębiorstw. Uzyskany materiał empiryczny przedstawiono w postaci studium przypadku.

Słowa kluczowe: społeczna odpowiedzilaność biznesu, zarządzanie różnorodnością, kapitał ludzki, strategia biznesowa, zrównoważony rozwój. 